\title{
Menakar Resolusi Konflik di Dunia Islam
}

\section{Surwandono}

Jurusan IImu Hubungan Internasional, Fakultas IImu Sosial dan IImu Politik, Universitas

Muhammadiyah Yogyakarta

Ringroad Barat Tamantirto, Kasihan, Bantul 55183

Email:Surwan04@yahoo.co.au

\begin{abstract}
Islamic history has shown that Islam was born in a state of conflict which acute, both local and international levels. Thus, it's really important to explore the structure of Islamic values which very appreciative with the spirit of "peace, security, fully-accepted, obey" as defined in the word Islam itself. This paper argues that the history of Muhammad prophet leadership gave a clear lesson about how Islamic perspectives in resolving conflict of various levels:community, country, and in the arena of International relations.

Keywords:conflict resolution, Islamic World, the religion of peace, a zero sum game, a positive sum game

Abstrak

Sejarah Islam telah menunjukkan bahwa Islam lahir dalam kondisi konflik yang sangat akut di tingkat lokal maupun di tingkat internasional. Dengan demikian menjadi teramat penting untuk menggali kembali struktur nilai Islam yang sangat apresiatif dengan semangat "kedamaian, keselamatan, pasrah, tunduk" yang tertera dalam kata Islam itu sendiri. Tulisan ini berargumen bahwa sejarah kepemimpinan Nabi Muhammad memberi pelajaran yang jelas tentang bagaimana pandangan Islam dalam menyelesaikan konflik dari berbagai level:komunitas, negara dan dalam arena hubungan antar bangsa.

Kata kunci: Resolusi konflik, Dunia Islam, agama kedamaian, zero sum game, positive sum game
\end{abstract}

\section{PENDAHULUAN}

Konflik antara Amerika Serikat dengan Irak merupakan sebuah tragedi yang mengawali abad 21 bagi dunia Islam.Amerika Serikat juga telah menimpakan tragedy di Afghanistan setelah Amerika Serikat mengklaim telah "dizalimi" oleh Osamah bin Ladin. Bagaimana tidak, Umat Islam di seluruh dunia harus menghadapi dilemma untuk menentukan sikap antara memberikan dukungan dan menolak kepada AS yang secara nyata memang menunjukkan arogansinya atau membela Irak ataupun Afghanistan ketika itu yang tampak "subhat". Karena senyatanya Mullah Umar memberikan pembelaan habis-habisan kepada Osamah, dan AS secara sistematis mempropagandakan bahwa Osamah dibalik aksi teror dengan iming-iming janji bantuan ekonomi jika membantu AS. Demikian pula dengan kasus Irak, Irak memang sebelumnya memiliki senjata pemusnah massal, dalam bentuk senjata kimia dan biologis yang dikhawatirkan akan diakses oleh teroris mengancam kepentingan AS yang dipropagandakan oleh AS dapat mengancam dunia. Pilihan sulit ini pada akhirnya hanya melahirkan kata pahit yang berulang-ulang di mana hampir tidak bermakna untuk mengurangi arogansi Amerika Serikat.

Ketidakmampuan memberikan sikap ini merupakan cerminan bahwa dunia Islam hampir tidak memiliki agenda yang jelas untuk menapaki abad 21, sebagai abad yang sebelumnya didesain sebagai abad dunia Islam. Teramat banyak konflik di dunia Islam tidak mampu diselesaikan dengan baik oleh dunia Islam sendiri yang mengakibatkan intervensi fihak lain, semisal negara adikuasa, yang mengail di tengah kekeruhan dunia Islam.

Kenyataan ini harusnya mengugah setiap aktor dan 
elit di dunia Islam untuk keluar dari kondisi "subhat" ini dengan cara-cara cerdas dan kreatif. Jangan sampai menjadikan perkara "subhat" yang masih dharurat ini diperpanjang yang akan berakibat banyak perkara politik tidak terselesaikan karena kesemuanya melakukan politik "uzlah" atau ignorance yang secara akumulatif akan sangat berbahaya. Para elite Islam harusnya menyadari bagaimana pil pahit yang diderita Islam pasca Rasul, karena membiarkan atau tidak diperbincangkan dengan tuntas menjadikan perkara politik berkembang menjadi perkara aqidah yang berakibat lebih sulit terselesaikannya masalah.

\section{PEMBAHASAN}

TERORISME AGENDA DUNIA ISLAM YANG PERTAMA

Abad ke-21 yang sebelumnya akan disebut sebagai abad kesejahteraan dan ekonomi ternyata berputar haluan menjadi abad kekerasan dan perang. Tesis Huntington ternyata lebih valid dibandingkan dengan tesis Naisbitt.Bagi dunia Islam abad 21 merupakan abad yang banyak diyakini sebagai abad transisi kekuasaan material ke kekuasaan moral. Runtuhnya regim komunisme Uni Soviet dipahami sebagai awal keruntuhan mazhab materialisme histories, dan pada akhirnya regim materialisme lainnya seperti individualisme-kapitalisme juga akan mengalami gejala deklinasi.

Namun, krisis ekonomi dunia di akhir abad ke- 20 telah memberikan arah perubahan yang signifikan.Negara-negara kapitalis ternyata memiliki daya tahan yang cukup tinggi menghadapi efek kejut dari krisis ekonomi dan moneter.Namun dunia Islam tampaknya mengalami efek yang sangat serius semisal Indonesia dan Malaysia yang difahami sebagai calon eksponen kebangkitan Islam.Krisis ekonomi membuat agenda kebangkitan Islam di Asia tenggara mengalami penurunan yang signifikan.

Krisis ini juga kemudian mengimbas eksponen kebangkitan Islam dalam bidang politik, Malaysia harus menelan pil pahit, eksponen Anwar Ibrahim diisolasikan dari politik setelah dipenjarakan oleh Mahathir Muhammad.UMNO semakin artikulatif dengan nasionalismenya, dan perlahan terdapat marginalisasi peran politik Islam meski telah hadir partai opisisi partai Keadilan Nasional pimpinan Wan Azizah dan PAS.Di Indonesia juga demikian halnya, gerak laju ICMI yang dahulu difahami sebagai calon eksponen kebangkitan Islam di Indonesia juga mengalami peluruhan artikulasi pasca runtuhnya regim Suharto dan Habibi. Meski di sisi lain banyak lahir artikulasi politik Islam dalam partai politik dan kelompok kepentingan yang dinamis.

Di tingkat global, aktivisme kebangkitan Islam akhirnya banyak dijalankan secara artikulatif dan ekspresif oleh kelompok atau organisasi keislaman. Kemandulan negara-negara berbasis Muslim dalam bargaining position dengan regim adikuasa memberikan peluang bagi akselerasi organisasi militan seperti alQaeda. Al-Qaeda merupakan organisasi bentukan Osamah bin Laden, seorang milyader kebangsaan Arab yang kemudian membantu proyek Islamisasi di Afghanistan yang dilakukan regim Taliban. Demikian pula di tingkat nasional, tampilnya kelompok Islam "militan", yang sebelumnya relatif "tiarap" dengan ruang reformasi memberikan artikulasi yang sangat signifikan.

Dari sinilah issue terorisme kemudian disematkan kepada banyak organisasi Islam "militan" secara massif oleh Amerika Serikat dan dianggap memiliki jaringan yang lebih terorganisir dari aktor teroris negara seperti Iran, Iraq, Sudan, Afghanistan, dan Libia. KTT terorisme yang diprakarsai AS di Mesir tahun 1995 sebelumnya banyak diorientasikan untuk mengucilkan negara teroris, namun sekarang lebih banyak diorientasikan kepada INGO "teroris". Sehingga PBB sampai memberikan daftar kelompok "INGO" yang harus diwaspadai.

Dunia Islam yang sebelumnya sudah menampakkan hubungan yang membaik, redanya hubungan konfliktual Sunni-Syi'ah, Irak-Iran, Iraq-Suriah, ArabIsrael.Fakta yang cukup melegakan adalah diterima Iran sebagai negara yang selama ini dikucilkan oleh komunitas negara Islam dan dunia internasional menjadi figur ketua OKI. Sikap moderasi ini pada awalnya diharapkan akan menjadi embrio penyelesaian konflik di dunia Islam. Dengan kemampuan resolusi 
ini diharapkan akan bisa mengurangi "intervensi" negara adikuasa yang selama ini menjadi "trouble maker" dalam proses penyelesaian konflik.

Namun issue terorisme yang sedemikian "menyengat" ini membuat intervensi negara adikuasa AS semakin menunjukkan semangat intervensi yang arogan. AS tidak mengindahkan desakan internasional ketika melakukan serangan ke Afghanistan. Demikian pula ketika tanggal 20 Maret 2003 juga menjadi "doom day' bagi Iraq yang akan dihujani amunisi perang oleh AS dan sekutunya, jika ultimatum sang "kaisar" arogansi Bush tidak diindahkan.

\section{RESOLUSI KONFLIK:AGENDA KEDUA KEBANGKITAN ISLAM}

Dua pengalaman pahit Afghanistan dan Iraq merupakan stimulus yang harusnya segera menyadarkan para elite politik islam. Pertengkaran politik di internal dunia islam, bukan saja tidak produktif dan sangat bertentangan dengan semangat muamallah yang senantiasa mengedepankan akhlaqul karimah, seperti karamah insaniyah, ta'awun insani, huriyyah, fadhilah (Abu Zahrah,1980). Pertengkaran ini juga sekaligus akan mengundang intervensi fihak lain yang bisa memperumit konflik muamalah, yang sangat mungkin akan berpotensi menjadi konflik akidah atau ideologis (Abu Zahrah,1996). Politik sebagai bagian dari proses muamallah harusnya bisa diselesaikan dengan mekanisme mu'amalah pula. Ishlah atau resolusi konflik harus segera didesain

Dari sini bisa diidentifikasi sejauh mana arti penting resolusi konflik. Pertama, resolusi konflik akan memungkinkan setiap persoalan yang terjadi di dunia Islam segera dimanajemen sedemikian rupa agar konflik hanya bergerak dalam dataran debates dan maksimal hanya dalam dataran game saja tidak sampai ke war(Allison dalam Mas'oed, 1992) Kedua, resolusi konflik akan menempatkan issue konflik tetap bergerak dalam dataran "muamalah" bukan dalam dataran "akidah". Ketiga, resolusi konflik akan memungkinkan upaya eliminasi terhadap camput tangan "fihak eksternal" semisal negara adikuasa yang sangat kooptatif. Keempat, resolusi konflik akan memungkinkan "energi" yang dimiliki di dunia Islam tidak terkuras dalam konteks "konflik yang tidak terlalu perlu" sehingga bisa diorientasikan bagi kesejahteraan umat. Negara Islam hendaknya mengambil contoh bagaimana kemakmuran di Eropa diawali dengan upaya serius negara Eropa untuk "membunuh" nafsu berperang sesama negara Eropa setelah tragedi PD I dan II.

Dalam literasi hubungan internasional konflik menurut John Spanier (1992) bisa dipilah dalam beberapa hal:Pertama, konflik dalam area high-politics. Jenis konflik ini terjadi lebih berlandaskan pada issueissue keamanan, idiologi dan gejala persaingan antar negara yang bersifat prestise-politik baik yang bersifat global, regional maupun nasional, bahkan sub nasional. Ada kecenderungan konflik semacam ini akan menghasilkan pola penyelesaian zero-sum-game. Yakni permainan yang akan menghasilkan aktor yang menanng mutlak dan kalah mutlak, sehingga dalam tataran issue ini merupakan gejala either and or.

Kedua, konflik dalam area low politics(Spanier, 1992).Konflik ini terjadi lebih didasarkan pada issuissu ekonomi, sosial, budaya, teknologi, lingkungan, dan gejala persaingan antar negara cenderung bersifat pragmatisme politik, sehingga dalam batas tertentu ini merupakan perpanjangan gejala merkantilisme pada masa klasik. Ada kecenderungan konflik semacam ini akan menghasilkan pola penyelesaian non-zero-sum game. Yakni permainan yang memungkinkan terjadi tawar-menawar, sehingga akan tercipta formula kompromi antara fihak yang bersengketa. Kompromi inilah yang kemudian akan menjadi resolusinya, sehingga Charles Tilly menyatakan konflik semacam ini merupakan gejala issue more and less.

Studi yang mencoba mengeksplanasi tentang penyebab timbulnya kekerasan dan konflik telah dilakukan secara akumulatif, baik oleh Ted Gurr (1970:79) dengan teori deprivasi relatifnya, maupun Smelser (1971:79) dengan aspek yang mendukung terciptanya konflik.Teori yang lebih mutakhir mencoba menjelaskan konflik dari sisi inherensi dan kontigensinya.Teori ini dikemukakan oleh Henry Eickstein (1964:142) yang menyatakan terdapat sejumlah konflik yang terjadi lebih didasarkan karena 
terdapatnya persoalan internal yang kemudian ditansformasikan ke luar.

Hal serupa juga telah disampaikan oleh Wolter S. Jones yang dinyatakan dalam bentuk lain dengan penciptaan integrasi bersama melalui penciptaan musuh bersama. Dari sisi kontigensi lebih disebabkan karena terciptanya milieu atau lingkungan yang akan membentuk konflik. Jadi konflik lebih disebabkan oleh persoalan ekternal yang dalam batas tertentu sebagai hasil rekayasa dari fihak lain, atau dikondusifkan secara struktural oleh lingkungan. Smelser maupun Jones tampaknya juga telah mengidentifikasinya dalam literasi sebelumnya.

Literasi yang mencoba menformulasikan resolusi konflik pernah dibangun oleh Coob dan Elder (1972) yang memetakan konflik dari 1) Luasnya konflik, yakni semakin luas konflik maka harus didekati dari banyak sisi. 2) Intensitas konflik, yakni semakin intens konflik maka harus didekati dengan resolusi yang juga intens. 3) Ketampakan konflik, semakin ketampakan tinggi juga harus didekati dengan formmulasi penyelesaian yang lebih jelas atau manifest.

Studi ini kemudian dikembangkan oleh William Ury (1999) yang mencoba menciptakan resolusi konflik dengan memberikan barrier agar ekskalasi konflik berjalan dengan lambat sehingga mudah diselesaikan. Setidak terdapat 3 langkah yang bisa dijalankan:1) Secara proaktif melakukan aktivitas resolusi konflik untuk menyalurkan ketegangan yang bersifat laten. 2) Segera menyelesaikan konflik yang muncul dipermukaan 3) Upaya pembendungan terhadap segala macam kekuatan perrtahanan yang potensial menyebabkan konflik.

\section{ISLAM DAN RESOLUSI KONFLIK}

Sejarah islam telah menunjukkan bahwa "Islam lahir" dalam kondisi konflik yang sangat akut di tingkat local maupun di tingkat internasional. Dengan demikian menjadi teramat penting untuk menggali kembali struktur nilai Islam yang sangat apresiatif dengan semangat "kedamaian, keselamatan, pasrah, tunduk" yang tertera dalam kata Islam itu sendiri. Banyak sekali ayat-ayat al-Qur'an memberikan informasi untuk proses penyelesaian masalah secara damai (Alquran, Surat 49:10). Bahkan dalam konteks berhadapan dengan pihak yang zalimpun, Islam memerintahkan untuk senantiasa berperilaku adil (Alquran, Surat 5:8).

Jika dilakukan penelusuran terhadap sejarah Islam akan banyak ditemukan banyak peristiwa besar yang menunjukkan bahwa Nabi terakhir Islam, Muhammad SAW telah melakukan prinsip non-violence dan sekaligus mengembangkan tehnologi resolusi konflik. Peristiwa semisal peletakkan kembali hajar Aswad, usaha mempersaudarakan suku Aus dan Khazraj dalam bai'ah I, mempersaudarakan Muhajirin dan Anshor, perjanjian Hudaibiyyah, bahkan tatkala kemenangan Islam dalam Futuh Makkah-pun, resolusi konflik lebih dikedepankan.

Dari sinilah kiranya sejarah umat Islam bisa dibangun kembali menjadi sebuah fakta masa kini.Rasululloh telah memberikan transfer of knowledge yang sedemikian rupa bisa dikemas menjadi sebuah tehnologi masa kini.Ketidaktersediaan literasi yang membahas secara spesifik tentang tehnologi resolusi konflik membuat banyak fihak termasuk para akademisi tidak banyak melirik kepada tehnologi resolusi konflik yang dikembangkan Islam.

Dalam al-Qur'an-pun sudah sangat tampak ayat yang berbicara secara jelas tentang teknologi resolusi konflik. Beberapa ayat dalam surat al-Hujurat secara tegas memberikan gambaran secara berurutan bagaimana menghadapi konflik, dan bagaimana sikap yang harus dijalankan untuk mencegah terjadinya konflik. Dari yang berbicara tentang "informasi” yang bias, mempersaudarakan, tidak saling mengolok-olok, mencari-cari kesalahan, dan ditutup dengan ayat komunikasi antar kelompok(Alquran, Surat 49:7-13).

\section{KESIMPULAN}

Berbijak dari perbincangan sebelumnya maka agenda serius yang harus segera dilaksanakan terbagi ke dalam dua hal. Pertama dalam hal bangunan konseptual dan kedua dalam bangunan praktis. Untuk dataran konseptual yang bisa dilakukan adalah:

- Menggali konsep struktur dan tehnologi resolusi 
konflik dalam islam dan dipadukan dengan struktur dan teknologi resolusi konflik yang juga telah berkembang di dunia akademis Barat

- Melakukan proses sosialiasi terhadap konsep dan struktur tersebut ke seluruh masyarakat islam

Dalam bidang praktis yang dapat dilakukan dengan melakukan proses sebagaimana rasul Muhammad melakukan bentuk "mempersaudarakan" kembali antara umat Islam. Sekat-sekat negara bangsa harus dieliminir jika sekat tersebut membuat rusaknya persaudaraan antar umat Islam. Proses mempersaudarakan ini harus dibuat secara alamiah melalui proses "kontrak social" dengan melakukan identifikasi konflik secara jelas dan fair. Kontrak social ini bukan hanya kepada dunia Islam, tetapi juga bisa dengan di luar dunia Islam seperti halnya Piagam Madinah.

Langkah berikutnya yang dilakukan adalah "revitalisasi" konsep nation-state yang selama ini kaku, ke dalam konsep nation-state yang relatif dinamis sebagai upaya menghindari bentuk-bentuk mobilisasi politik yang tidak terlalu relevan. Proses ini sebagai bentuk awal upaya membangun "packing order" di dunia Islam agar konflik kecil tidak berubah menjadi besar.

Dari langkah revitalisasi nation-state ini diharapkan mampu menciptakan kondisi sinergis bagi implementasi prinsip “Ta'awun Insani” yang lebih artikulatif dan membumi.Sebagaimana ditunjukkan kalangan Muhajirin dan Ashor yang sedemikian impresif, sehingga menjadi masyarakat Madinah menjadi masyarakat yang kompetitif dan demokratis.

\section{REFERENSI}

Abu Zahrah, Muhammad.1980. Hubungan Internasional Dalam Islam. Jakarta:Bulan Bintang

Jakarta:Logos

Al-Quranul Karim

Cobb, Roger dan Charles Elder.1972.Participation in American Politics: The Dynamics of Agenda-Buildin., Allyn and Bacon:Boston

Eickstein, Harry.1964. Internal War Problems and Approaches, London:The Free Press of Glencoe Collier Macmillan

Gurr, Ted.1970. Why Men Rebel. New Jersey:Princenton University
Press

Mas'oed, Mohtar. 1996. Ilmu Hubungan Internasional, :Disiplin dan Metodologi, Jakarta:LP3ES

Smelser, Neil. 1971. Theory of Collective Behaviour, New York:The Free Press

Spanier, John. 1992. Games Nations Playing. New York:

Ury, William.1999.Getting to Peace:Transforming Conflict at Home, at Work and in the World. New York 